\title{
Failure Analysis of PHILOS Plate Construct Used for Pantalar Arthrodesis Paper I-Analysis of the Plate
}

\author{
Jason Ina ${ }^{1}$, Madhurima Vallentyne ${ }^{2}$, Farah Hamandi ${ }^{2}$, Kathleen Shugart ${ }^{3}$, Michael Boin ${ }^{4}$, \\ Richard Laughlin ${ }^{4}$ and Tarun Goswami ${ }^{2,4, *}$ \\ 1 Boonshoft School of Medicine, Wright State University, Dayton, OH 45435, USA; ina.2@wright.edu \\ 2 Department of Biomedical, Industrial, and Human Factors Engineering, Wright State University, \\ Dayton 45435, OH, USA; vallentyne.2@wright.edu (M.V.); hamandi.3@wright.edu (F.H.) \\ 3 Materials Characterization Facility, UES Inc., 4401 Dayton-Xenia Road, Beavercreek, OH 45432, USA; \\ kathleen.cissel.ctr@us.af.mil \\ 4 Department of Orthopedic Surgery, Sports Medicine and Rehabilitation, Wright State University, Dayton, \\ OH 45435, USA; michael.boin@wright.edu (M.B.); richard.laughlin@wright.edu (R.L.) \\ * Correspondence: tarun.goswami@wright.edu; Tel.: +1-937-775-5120
}

Received: 21 December 2017; Accepted: 8 March 2018; Published: 13 March 2018

\begin{abstract}
The failure of a proximal humerus internal locking system (PHILOS) used in a pantalar arthrodesis was investigated in this paper. PHILOS constructs are hybrids using locking and non-locking screws. Both the plate and the screws used in the fusion were obtained for analysis. However, only the plate failure analysis is reported in this paper. The implant had failed in several pieces. Optical and scanning electron microscopic analyses were performed to characterize the failure mode(s) and fracture surface. The chemical composition and mechanical properties of the plate were determined and compared to controlling specifications to manufacture the devices. We found that equivalent tensile strength exceeded at the locations of high stress, axial, and angular displacement and matched the specification at the regions of lower stress/displacement. Such a region-wise change in mechanical properties with in vivo utilization has not been reported in the literature. Evidence of inclusions was qualitatively determined for the stainless steel 316L plate failing the specifications. Pitting corrosion, scratches, discoloration and debris were present on the plate. Fracture surface showed (1) multi-site corrosion damage within the screw holes forming a $45^{\circ}$ maximum shear force line for crack-linking, and (2) crack propagation perpendicular to the crack forming origin that may have formed due to the presence of inclusions. Fracture features such as beach marks and striations indicating that corrosion may have initiated the crack(s), which grew by fatigue over a period of time. In conclusion, the most likely mechanism of failure for the device was due to corrosion fatigue and lack of bony in-growth on the screws that may have caused loosening of the device causing deformity and pre-mature failure.
\end{abstract}

Keywords: pantalar; arthrodesis; failure modes; fracture surface; corrosion; scratching

\section{Introduction}

Arthrodesis has served as a standard treatment for painful arthritis of the ankle and the subtalar joints. The ankle joint is composed of the tibia and fibula and the subtalar joint includes the talus and calcaneus [1]. Fusion of the ankle, subtalar, and talonavicular joints together is known as pantalar arthrodesis and has been performed by orthopaedic surgeons since 1906 [2]. There also are non-surgical treatment methods such as non-steroidal anti-inflammatory medications and prefabricated or custom orthotics, but these methods are not effective in all patients.

Pantalar arthrodesis can be achieved with internal or external fixation. Internal fixation is preferred in most cases as it has many advantages over external fixations. The incidence of 
non-unions and mal-unions are reduced with internal fixation [3]. Implants that can be used for internal fixation are plates, screws, intramedullary nails, and wires. Locking compression plates (LCP) are advantageous when compared to others since they provide an angular-stable interface. LCPs are most commonly used for acute traumatic fractures, osteotomy fixation, non-union repair, and arthrodesis [4]. In the compression plating technique with conventional screws, primary stability is achieved by the compression between the plate and the bone. However, since there is no direct contact between the plate and the bone, the primary stability achieved by compression may be lost due to cyclic loading. The two major mechanisms for fixation failure in these constructs are axial tilting in the absence of the normal support given by bone due to fracture comminution and screw loosening in osteoporotic bone. In these cases, locking screws are preferred to conventional screw to limit these mechanisms of failure. Because locking screws lock into the locking plate, the amount of axial tilt and screw loosening is minimized. Proximal humerus internal locking system (PHILOS) (Figure 1) plating used in the pantalar joint utilizes the benefit that blood supply to the bone is preserved and soft-tissue injury minimized due to lack of compression. In addition, successful fixation result in anatomic reduction, stable fixation, preservation of blood supply, and early mobilization [5-9] which occur with the use of locking compression technology.
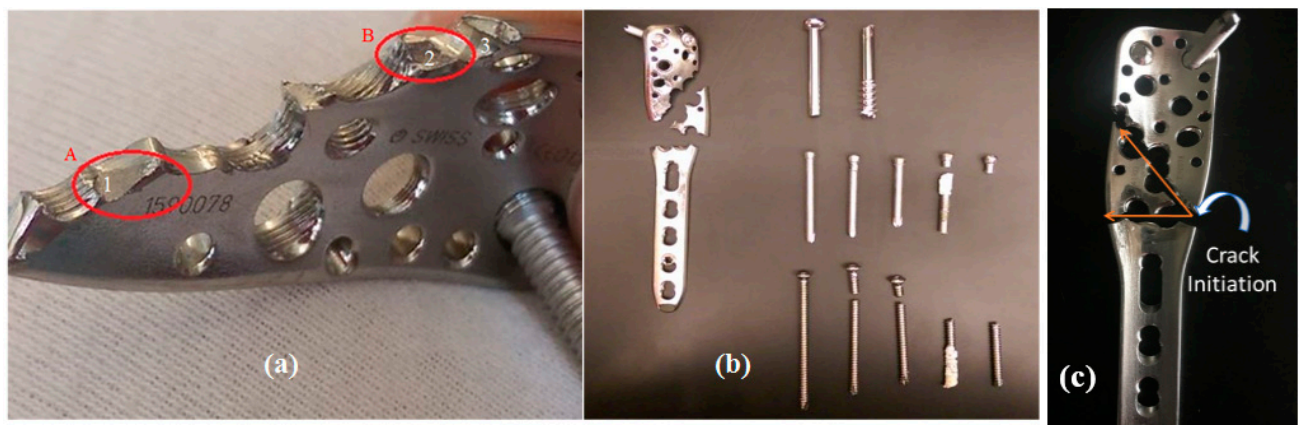

Figure 1. Submitted proximal humerus internal locking system (PHILOS) device for analysis; (a) plate through the thickness shows regions of interests marked by A and B and 1-3 investigated in this paper (b) the failed samples and (c) crack initiation and propagation of the plate.

A summary of device failures was compiled from literature [10-23] (see Appendix A). It identifies the devices, material of construction, failure modes and other fracture features. It is noteworthy that this may be the only case involving the failure analysis of PHILOS (Figure 1). A number of studies involving SS316L material revealed inclusion sites as crack origins [10,15-18], corrosion, wear and fatigue $[10-13,15,16,18,19,21,23]$ with no visible mechanical failure yet having failed clinically [12,14]. The majority of the devices were constructed with SS 316 and 316L; however, a few devices constructed with Ti-6Al-4V alloy [19-22] and pure titanium [23] were also found. From this summary it is prudent to investigate the chemical composition and inclusions that form pitting and corrosion fatigue related failures of the devices.

\subsection{Case Presentation (Clinical Summary)}

\subsubsection{Initial Presentation}

A 68-year-old female was seen in the office for a right foot deformity. She experienced changes in ambulation over the past month with no history of trauma. Other than her progressive ankle deformity, she was relatively healthy.

On physical exam there was a fixed, non-reducible deformity of the right ankle. Palpable posterior tibial and dorsalis pedis pulses were present. Sensation over the dorsal and plantar foot was intact to light touch. Initial ankle X-rays were significant for a right ankle deformity consistent with chronic lateral subtalar dislocation with varus tibiotalar joint alignment (Appendix B, Figures A1 and A2). 
There was no evidence of bone loss or acute fracture. It was determined that the patient required a right ankle pantalar arthrodesis.

\subsubsection{Operation}

A $3.5 \mathrm{~mm}$ LCP PHILOS (Synthes, Solothurn, Switzerland) was inverted so that the locking screws could be inserted into both the talus and calcaneus and compression screws into the tibia. The plate was fixed to the lateral portion of the calcaneus and tibia using four $3.5 \mathrm{~mm}$ cortical screws proximally in the tibia and seven $3.5 \mathrm{~mm}$ locking screws distally. A 6.5 cannulated screw (Zimmer, Warsaw, IN, USA) was placed from the tibia across the talus and into the calcaneus to provide compression across the tibiotalar and subtalar joints. Three additional $3.5 \mathrm{~mm}$ screws with washers were placed from the navicular into the talus in order to fuse the talonavicular joint.

An additional $3.5 \mathrm{~mm}$ screw and washer were inserted from the anterior process of the calcaneus to the cuboid to achieve fusion at this joint. The patient was to remain non-weight bearing on her surgical extremity for three months.

\subsubsection{Post-Operative Follow-Up}

Clinically, in the first year of follow up appointments, the patient was doing very well. Weight bearing as tolerated began after three months. She returned to the surgeon's office once yearly for follow up. During every follow up, new imaging (by X-ray) of the ankle was obtained. Imaging over this time showed that her ankle did not fuse and formed a non-union. Her hardware failed as seen with radiographic evidence of breakage. The hardware breakage progressed from a single screw to involving multiple screws and the plate over the post-operative course. At six years post-operative she complained of a new onset pain in her operative ankle. With the new onset symptoms and evidence of failed fusion and hardware failure, a removal of hardware and revision ankle fusion was planned.

\subsubsection{Post-Operative Imaging}

X-rays from the 18-month post-op visit showed evidence of breakage of a distal $3.5 \mathrm{~mm}$ talonavicular screw (Figure A2). The fracture line was located in the thread near the screw head. At two years post-op, the screw breakage was more displaced and there was an additional fracture in the most proximal $3.5 \mathrm{~mm}$ cortical screw in the tibia (Figure A3). The fracture line of this screw was again in the thread near the screw head. At three years post-op, a new fracture of the most proximal $3.5 \mathrm{~mm}$ locking screw in the talus was present (Figure A4). There was also evidence of a newly forming valgus deformity. At five years post-op, an additional $3.5 \mathrm{~mm}$ cortical screw in the tibia, a second $3.5 \mathrm{~mm}$ talonavicular screw, the $6.5 \mathrm{~mm}$ cannulated screw, and the $3.5 \mathrm{~mm}$ LCP plate all exhibited fracture on imaging (Figure A5). At six years post-op, an additional $3.5 \mathrm{~mm}$ cortical screw in the tibia broke and the fractured plate became more widely displaced (Figure A6). The valgus deformity seen earlier had now progressed to nearly 30 degrees.

\section{Materials and Methods}

The PHILOS plate was made of Stainless Steel 316L, originally manufactured by Synthes, now Depuy Synthes Joint Reconstruction (Warsaw, IN, USA). The plate is anatomically shaped to the complex contours of the proximal humerus. The construct contains both locking and combination of locking and compression holes using different types of screws [24,25]. There are 10 locking holes in the distal end of the PHILOS permitting multiple points of fixation for support. The PHILOS has 5 combination holes, one elongated hole to aid in-plate positioning with a $3.5 \mathrm{~mm}$ locking screws hole in the threaded portion in the proximal shaft. There are also 3.5 and $4.0 \mathrm{~mm}$ cortical screw holes and $4.0 \mathrm{~mm}$ cancellous bone screws in the compression portion. All 18 pieces of the implant submitted for investigation are shown in Figure 1. Among the submitted pieces, only 4 screws were intact. The LCP, 
which was fractured into three pieces, was measured to be $114 \mathrm{~mm}$ in length and had a thickness of $3.5 \mathrm{~mm}$.

In order to assess the mechanical and manufacturing integrity of the failed device, we preformed Rockwell hardness B-scale test and X-ray energy dispersive spectroscopy (EDS) using a Quanta 600 scanning electron microscope (SEM, Thermo Fisher Scientific, Hillsboro, OR, USA) with a $15 \mathrm{kV}$ voltage and a spot size of 5 . We compared the results from our testing to ASTM (American Society for Testing and Materials) standards reported for stainless steel 316L [26]. The Rockwell hardness test was performed in three different locations of the fractured plate with each test location increasing in distance away from the fracture surface. The EDS was performed using a $10 \mathrm{~mm}$ square detector and genesis software package. EDS was performed on both the fracture plate. EDS samples were taken both at the plate surface and plate interior to ensure homogeneity throughout both pieces.

One of the plate fragments was cleaned in ethanol followed by water sonication for $10 \mathrm{~min}$ to study the fracture surface. Fractography was performed using the SEM with a voltage of $15 \mathrm{kV}$ and a spot size of 3. Electron backscatter diffraction (EBSD) was performed on an FEIXL-30 using an EDAX EBSD detector to determine the grain size and orientation.

\section{Results and Discussion}

\subsection{Chemical Composition Characterization}

The results of the X-ray EDS for the fracture plate is shown in Table 1 and compared with reported ASTM standard for SS 316L stainless steel (F138-03). An additional requirement set forth by the ASTM standard is shown in Equation (1), which yielded 24.77 for the plate [26]. One factor to keep in mind when comparing EDS results to the ASTM standard is that EDS is known to be a semi-quantitative technique. In addition, adventitious carbon may have accumulated on the surface preventing $C$ from being quantified. There is also an overlap between the X-ray peaks of Mo and S, precluding deconvolution of their concentrations. The EDS system used in this case was not sensitive enough to detect the trace amounts of $\mathrm{P}, \mathrm{S}$, and $\mathrm{N}$ expected according to the standard. The EDS spectrum is shown in Figure 2.

$$
\% \mathrm{Cr}+3.3 \times \% \mathrm{Mo} \geq 26.0
$$

Table 1. X-Ray energy dispersive spectroscopy (EDS) measured composition for plate (wt \%).

\begin{tabular}{cccc}
\hline Composition & ASTM Standard (Max) & Plate (Average) & Tolerance Limits \\
\hline $\mathrm{C}$ & 0.03 & - & 0.005 \\
$\mathrm{Mn}$ & 2.0 & 1.81 & 0.04 \\
$\mathrm{Si}$ & 0.75 & 0.59 & 0.05 \\
$\mathrm{P}$ & 0.025 & - & 0.005 \\
$\mathrm{~S}$ & 0.01 & - & 0.005 \\
$\mathrm{Cr}$ & $17-19$ & 17.61 & 0.05 \\
$\mathrm{Mo}$ & $2.25-3.0$ & 2.17 & 0.15 \\
$\mathrm{Ni}$ & $13-15$ & 13.84 & 0.2 \\
$\mathrm{~N}$ & 0.10 & - & 0.01 \\
$\mathrm{Fe}$ & Balance & 63.99 & - \\
\hline
\end{tabular}




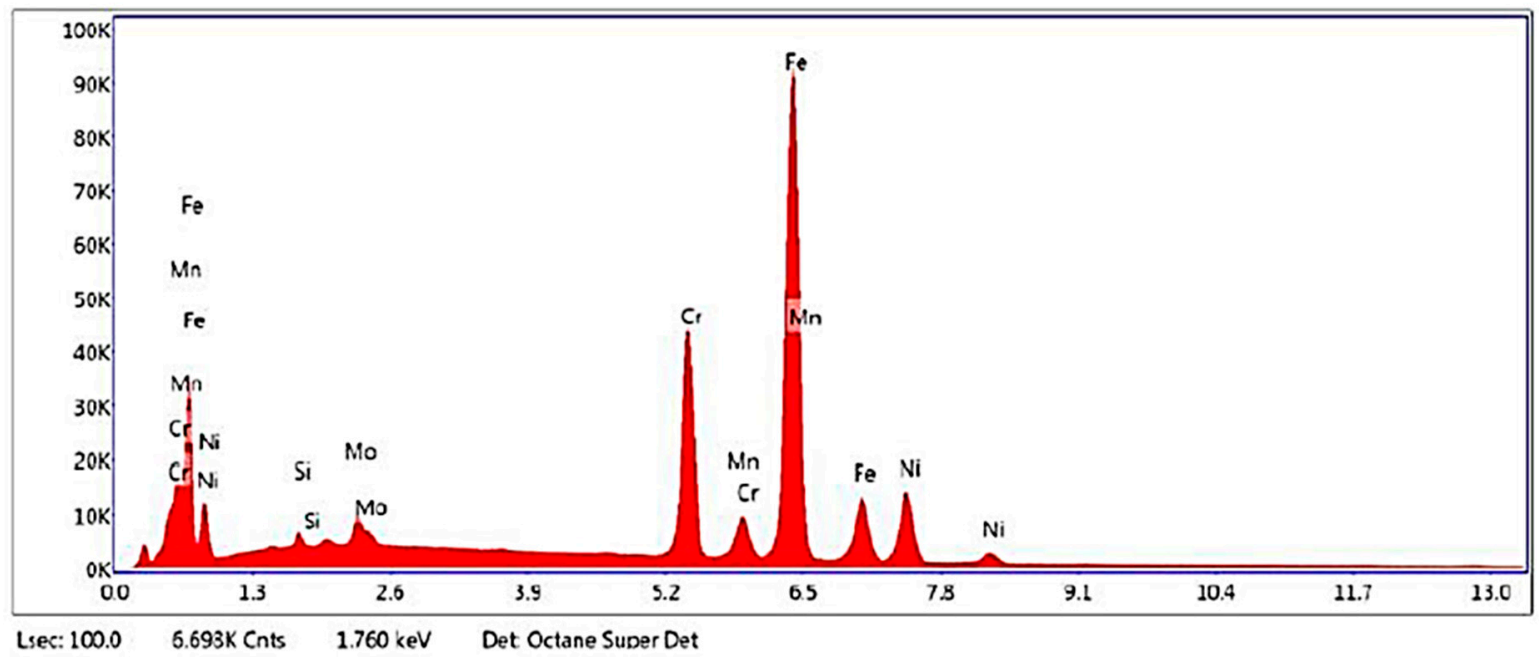

Figure 2. Energy dispersive $\mathrm{X}$-ray analysis shows qualitatively the peaks of different element weight percent present in the PHILOS plate.

The plate conformed to ASTM standards according to the tolerated ranges of element composition but failed equation 1 in this instance shown in Table 1 . However, in another instance, the results of the composition analysis gave a result of 28.7 for Equation (1), thus passing the requirements.

\subsection{Microstructural Characterization}

EBSD and backscatter imaging methods were used to characterize the structure of the material. The microstructure is shown in Figure 3. The range in the average grain size of the plate was four to six micrometers shown in Figure 4.

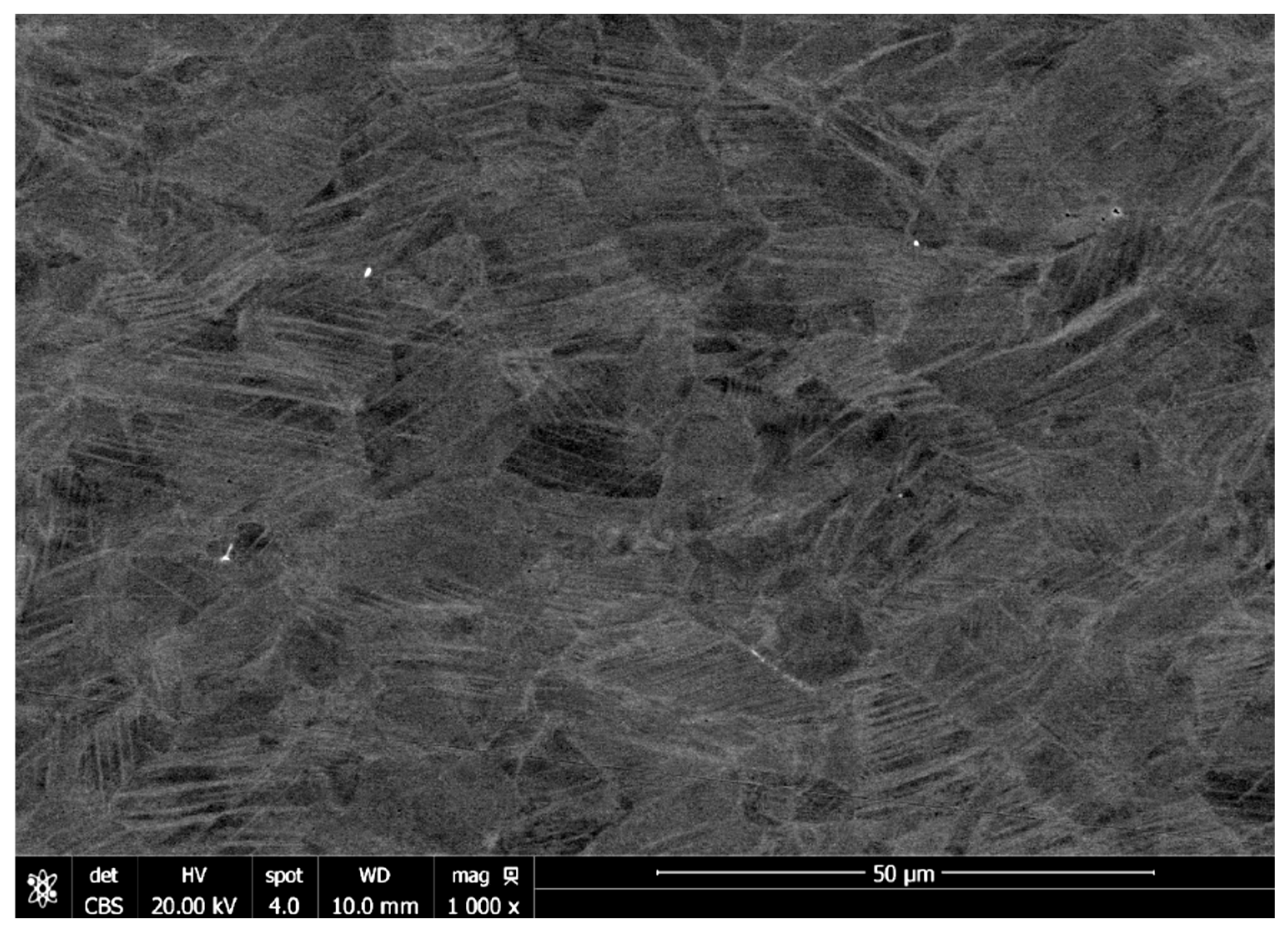

Figure 3. Microstructure of PHILOS plate at $1000 \times$. 


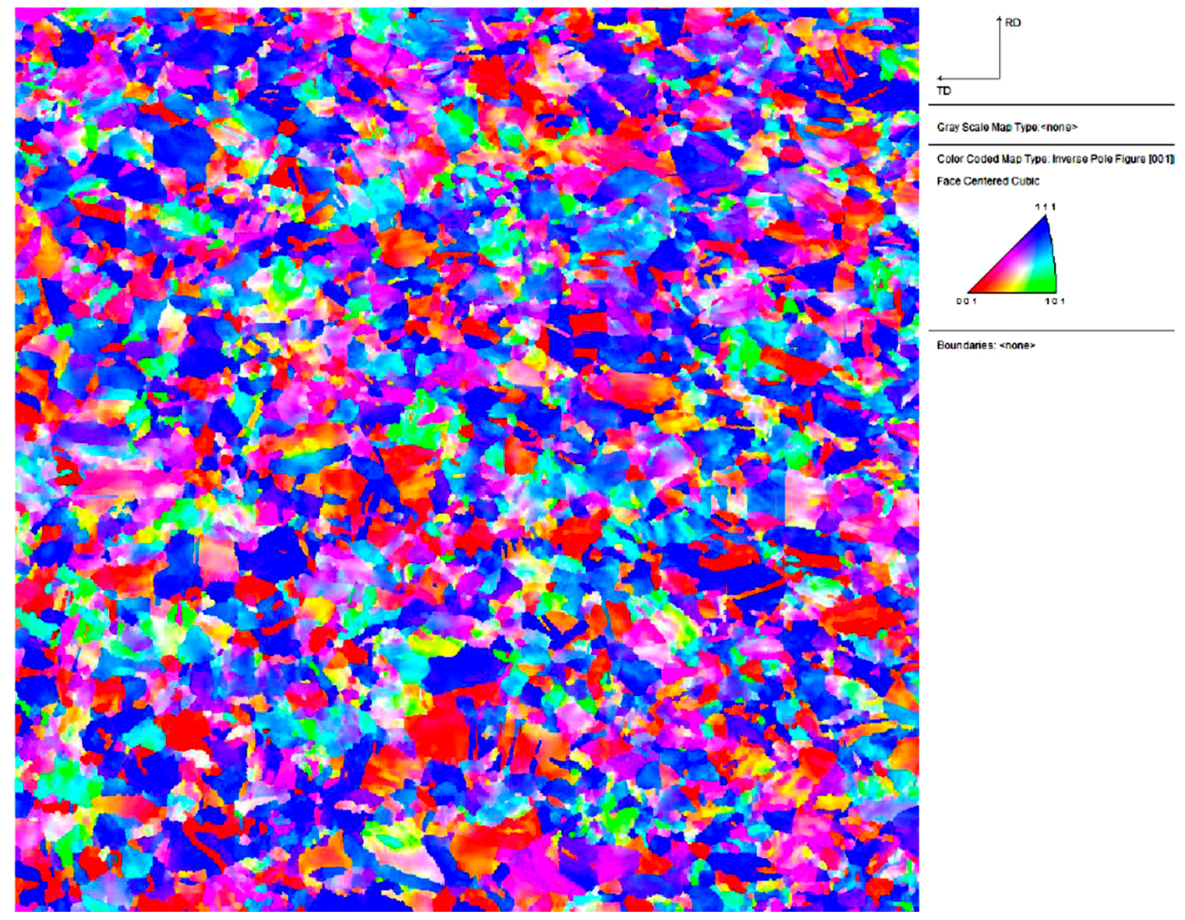

Figure 4. Electron backscatter diffraction (EBSD) grain map of the PHILOS plate.

An attempt was made to identify and characterize the inclusions. Two regions of interest identified in Figure 1 as area 2 and 3, were investigated for inclusions and presented in Figure 5a,b. The composition of one inclusion was mapped in Figure 6 using EDS. The maps in Figure 6 show that inclusions are likely Mo rich (though this could be S), these inclusions may be fine, localized chi and sigma intermetallic phases which may have started the crack. There is a need to characterize inclusions in surgical grade SS 316 as a dedicated basic research focus since this paper deals with failure analysis and the importance that the inclusions have on failure initiation.
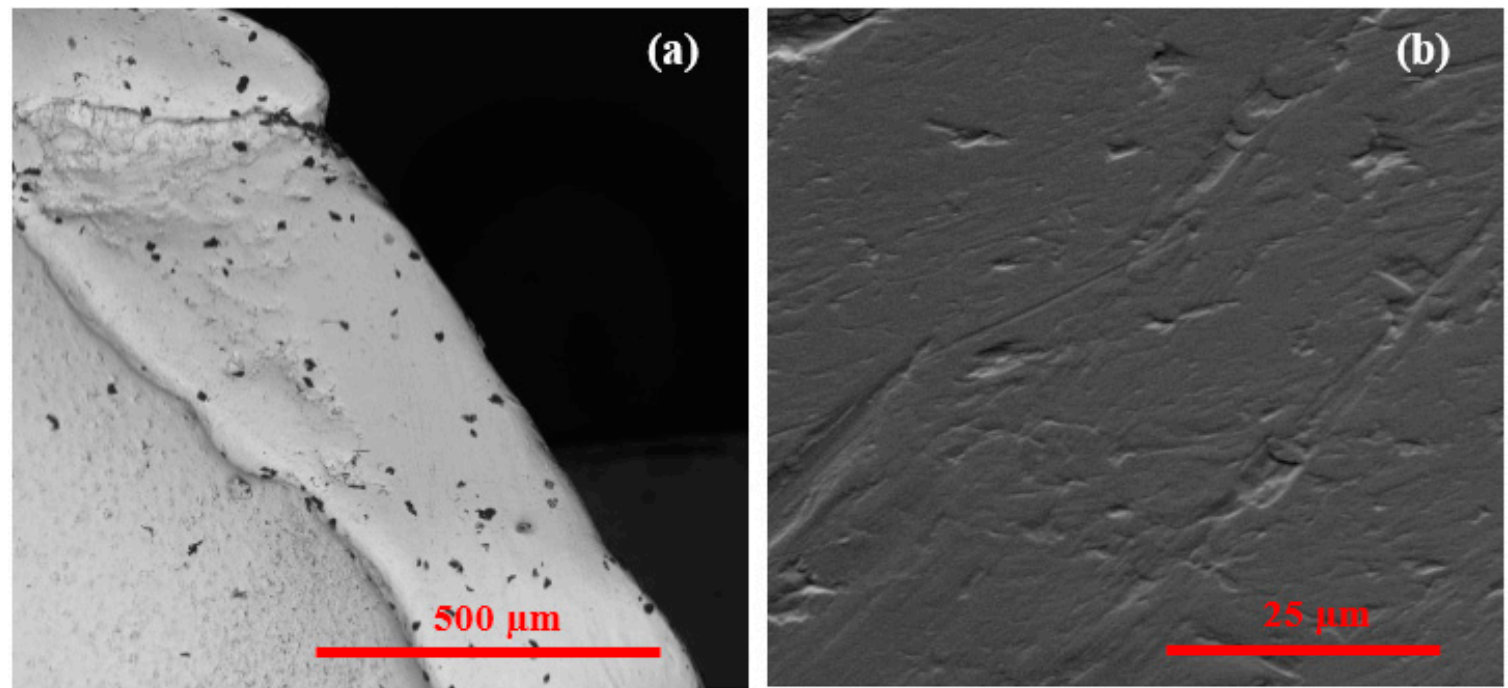

Figure 5. Backscattered electron images of likely inclusions (a) SEM EBSD image of area 2 (b) Topographical SEM image of area 3. 

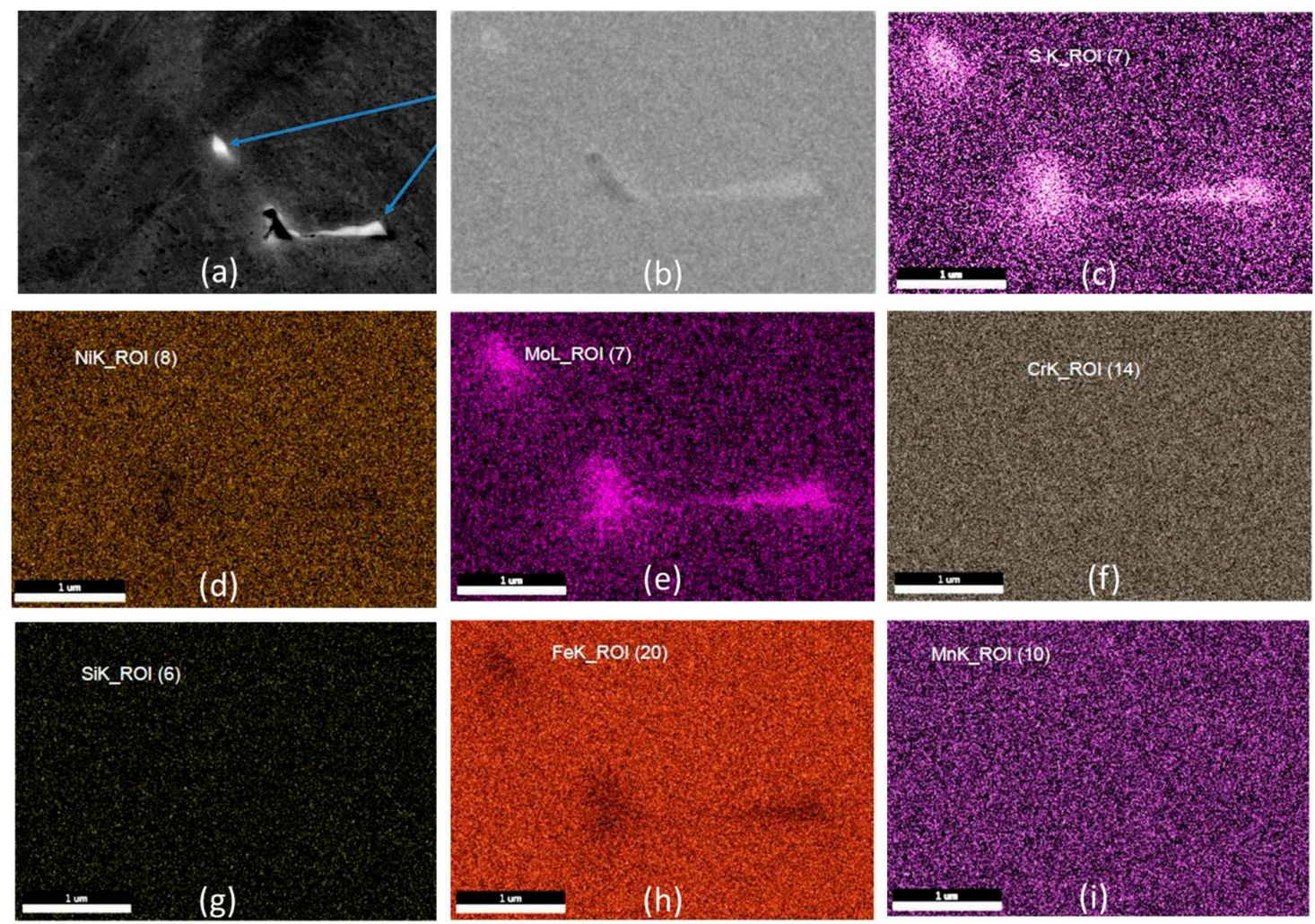

Figure 6. Characterization of inclusions using EDS. (a) The inclusions, (b) Gray scale of inclusions. Overlapping spectra of S and Mo visible in (c) Sulfur and/or (d) Nickel, (e) Molybdenum in the microstructure of the PHILOS plate. While the rest (f) Chromium, (g) Silicon, (h) Iron and (i) Manganese are not visible.

\subsection{Material Property Analysis}

The results of the Rockwell hardness B-scale test on the fractured plate are shown in Table 2. The ASTM standard upper limit for SS 316L is $95 \mathrm{HRB}$, and a $95 \%$ confidence interval was calculated for each trial. The hardness was then converted to Vickers hardness and tensile strength, and a 95\% confidence interval was also calculated and used to compare against the ASTM standard for SS316L [26]. Hardness of the plate varied across the plate. It is evident that as the fatigue related deformation accrued, the material hardened across or near the fracture plane. It is likely that the material may have been supplied at higher strength conditions via cold working and may also have had reduced elongation.

Table 2. Rockwell hardness B-scale test, Vickers hardness, and tensile strength results.

\begin{tabular}{cccccc}
\hline The Test & Average & ASTM Standard & Proximal & Middle & Distal \\
\hline \multirow{2}{*}{ Rockwell hardness } & Average & 95 & 101.8 & 107.7 & 107.8 \\
& $95 \%$ confidence interval & - & $101.1-102.5$ & $106.1-109.3$ & $106.6-109.5$ \\
\hline \multirow{2}{*}{ Vickers hardness } & Average & 213 & 266.5 & 330 & 334.5 \\
& $95 \%$ confidence interval & - & $260-273$ & $310-350$ & $316-353$ \\
\hline \multirow{2}{*}{ Tensile strength (psi) } & Average (MPa) & 868 & 848 & 1057 & 1057 \\
& $95 \%$ confidence interval & - & $837-859$ & $1004-1110$ & $1004-1110$ \\
\hline
\end{tabular}

\subsection{Optical Microscopic Analysis}

Visual observation indicated a large number of scratches on the surface of the plate. Two broken screw heads (with StarDrive recess) remained in the plate, while one partially intact locking screw 
was not removed from the distal end. Figure 1 shows that the crack initiated from under one of the locking screw holes near the middle of the plate. This fracture initiation has progressed in two different directions, one diagonally $45^{\circ}$ in the directions of maximum shear and one perpendicularly (Figure 1), which caused the plate to fail into three pieces. The observed features are summarized in Table 3. Since the plate and screw construct was removed after it had failed, we do not know whether the material dissolution or contact between two mating surfaces during removal removed the pitting and or other localized damage sites prior to crack formation.

Table 3. Various damage features on different parts of implant.

\begin{tabular}{cc}
\hline Location & Damage Feature(s) \\
\hline Distal area (Figure 1B) & Scratches and pits \\
Close to fracture plane (Figure 1A) & Scratches, pits, corrosion, cracking \\
Area (A), (Figure 1) & Debris, discoloration \\
\hline
\end{tabular}

\subsection{Fractography}

The markings shown in Figure 7a are changes in surface elevation eluding to pitting in area of interest 3. Figure 5 shows EBSD image and distribution of different phases present in the material that may be described as non-metallic/inclusions. Non-metallic inclusions are known to be areas of stress concentration and increase the likelihood of pitting corrosion and secondary crack initiation. Sudhakar et al. and Kanchanomi et al. found that non-metallic inclusions initiated the eventual failure of devices in their studies $[13,18]$. This evidence of pitting and foreign body inclusions, seen in Figures 5 and 6 , respectively, supports secondary crack initiation due to corrosion-fatigue at these sites. Figure $8 \mathrm{a}-\mathrm{c}$ show fatigue striations in the areas of interest 1,2, and 3, respectively. Striations are evident within all three images. Figure 8 a also shows some evidence of cleavage and facets. The striation spacing in each image was measured and displayed in Table 4 . The arrows indicate the direction of crack propagation based on increase in striation spacing.
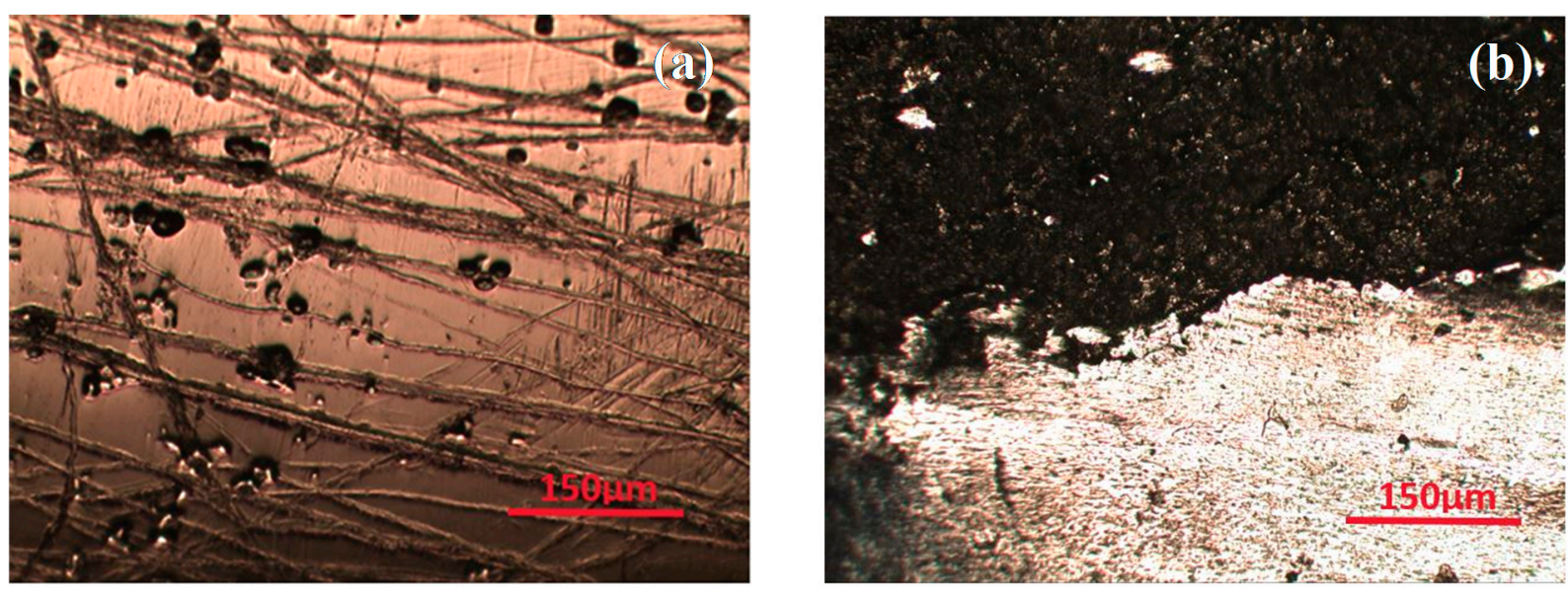

Figure 7. Light microscopy images showing (a) scratches and uniform pitting, and (b) debris and discoloration. 


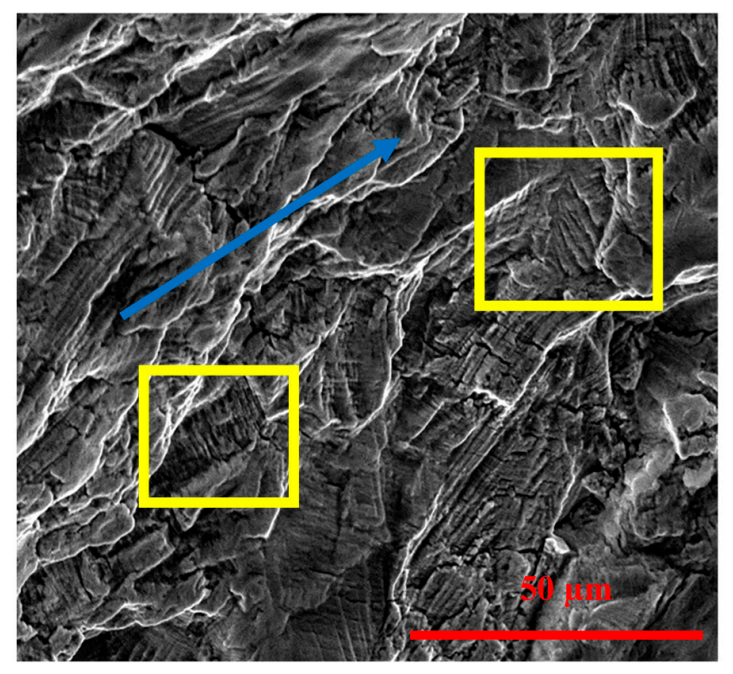

(a)

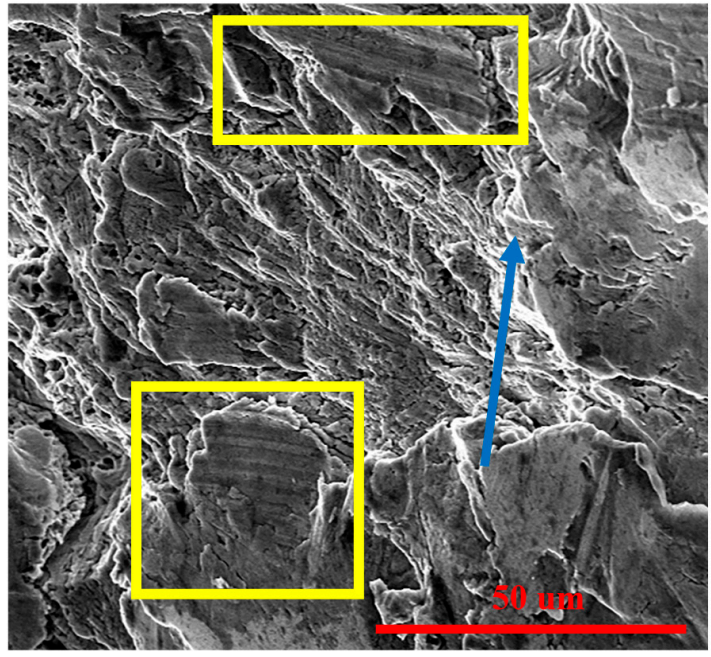

(b)

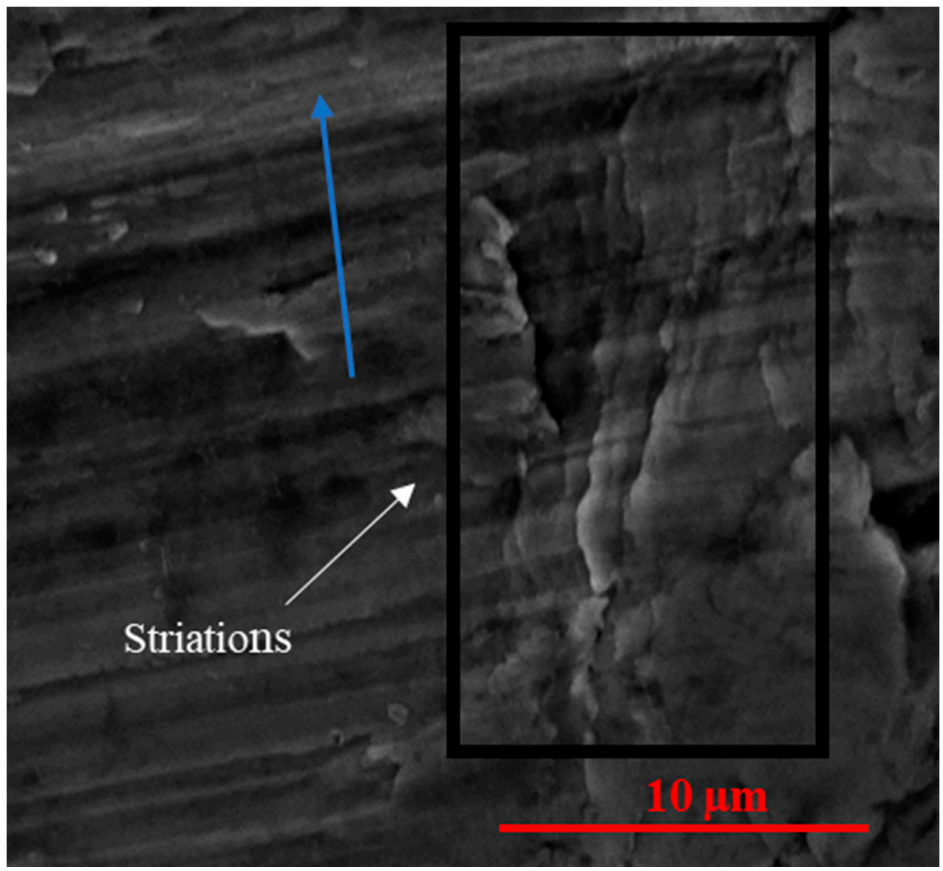

(c)

Figure 8. SEM images of (a) area 1, (b) area 2, and (c) area 3 showing striations perpendicular to crack propagation. The yellow boxes show striations and blue arrows denote the direction of crack propagation.

Table 4. Striation spacing range.

\begin{tabular}{cc}
\hline Reference Image & Striation Spacing $(\mu \mathrm{m})$ \\
\hline Figure 8c (area 3) & $0.44-0.99$ \\
Figure 8b (area 2) & $0.80-1.42$ \\
Figure 8a (area 1) & $1.91-4.95$ \\
\hline
\end{tabular}

From these methods it is quite clear that striation spacing increased as the crack advanced through the three regions, 3 to 1, respectively. The origin for crack appears to be from area 3 (distal end of plate, latterly); however, as it advanced, the linking occurred through the screw holes in a $45^{\circ}$ angle which may have coincided with dorsiflexion angle or slight movement by gait. Upon failure, the plate 
was not able to load bear along this angle, the load transferred perpendicularly causing cracking and linking through the screw holes in that direction as well.

The SEM imaging performed on the failed implant provides a strong argument for initial corrosion-fatigue fracture followed by brittle fracture for the mechanism of failure. Table A1 shows that Thapa et al., Karmacharya et al., Majid et al. and Azevedo et al. identified corrosion as an important factor in the failure of devices [11-13,19]. Fatigue fracture has been conservatively estimated to account for $50 \%$ of all brittle fractures in manufactured products, making fatigue fracture the most prevalent initiator of brittle fracture [27]. Striations due to secondary crack propagation were evident at multiple locations on the locking compression plate (Figure 8a-c). Thapa et al. came to the conclusion that a 10 hole locking compression plate led to failure after 2035 cycles with a striation spacing of 0.3-1.72 $\mu \mathrm{m}$ [14]. Goswami et al. showed striation spacing within a range of 10-15 $\mu \mathrm{m}$ for the fracture of an IM nail that led to an estimate of less than 100 cycles before fracture [22]. Based on the findings of previous research, it may be estimated that the plate may have accumulated a quarter of a million cycles by a stable crack propagation mechanism; however, as it jumped through the screw hole(s), the striation spacing increased. At location 1 , the striation spacing was wide enough that failure may have occurred in the tertiary phase of crack propagation. However, the kinetics of how an inclusion transitioned to pitting and pit to crack is not known. These findings support evidence of secondary crack initiation, within the areas of non-metallic inclusions, as shown in Figure 9. The fatigue failure mechanism for SS 316L was in terms of excessive twinning as shown in Figure 10. However, twinning may also be a standard microstructure of SS316L and the available samples were made from the failed device; we cannot conclude whether or not the twinning were original microstructure or as a result of in vivo use.

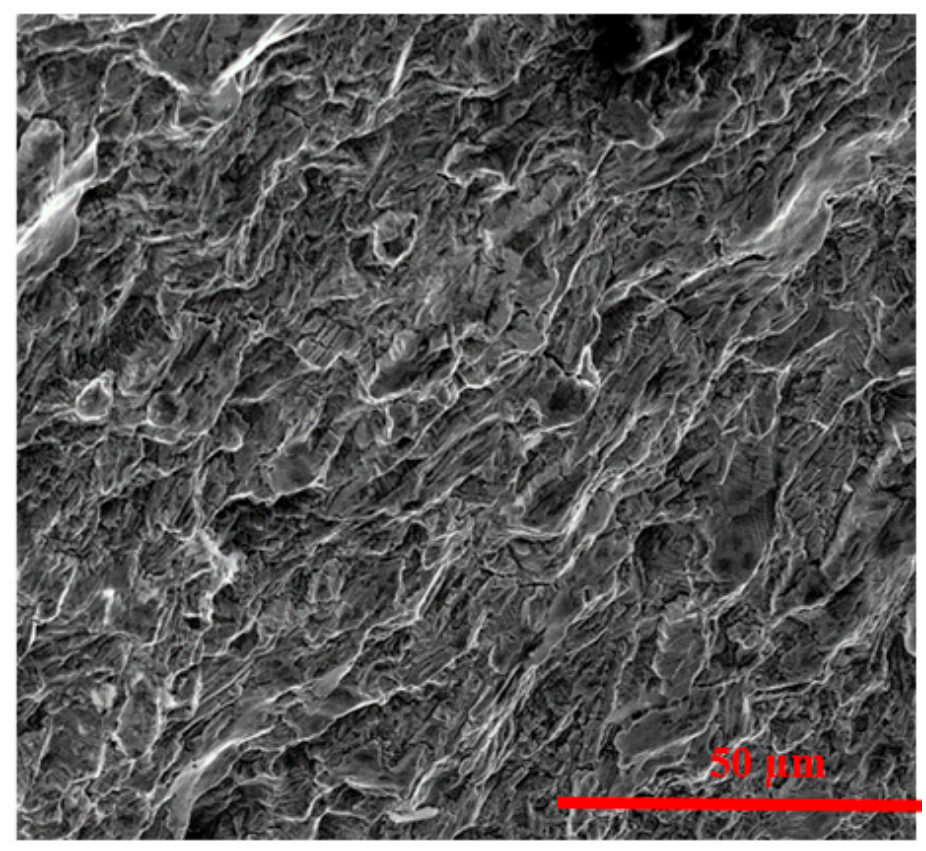

Figure 9. SEM image taken at area of interest 1 . This image contains examples of quasi-cleavages and facets. 


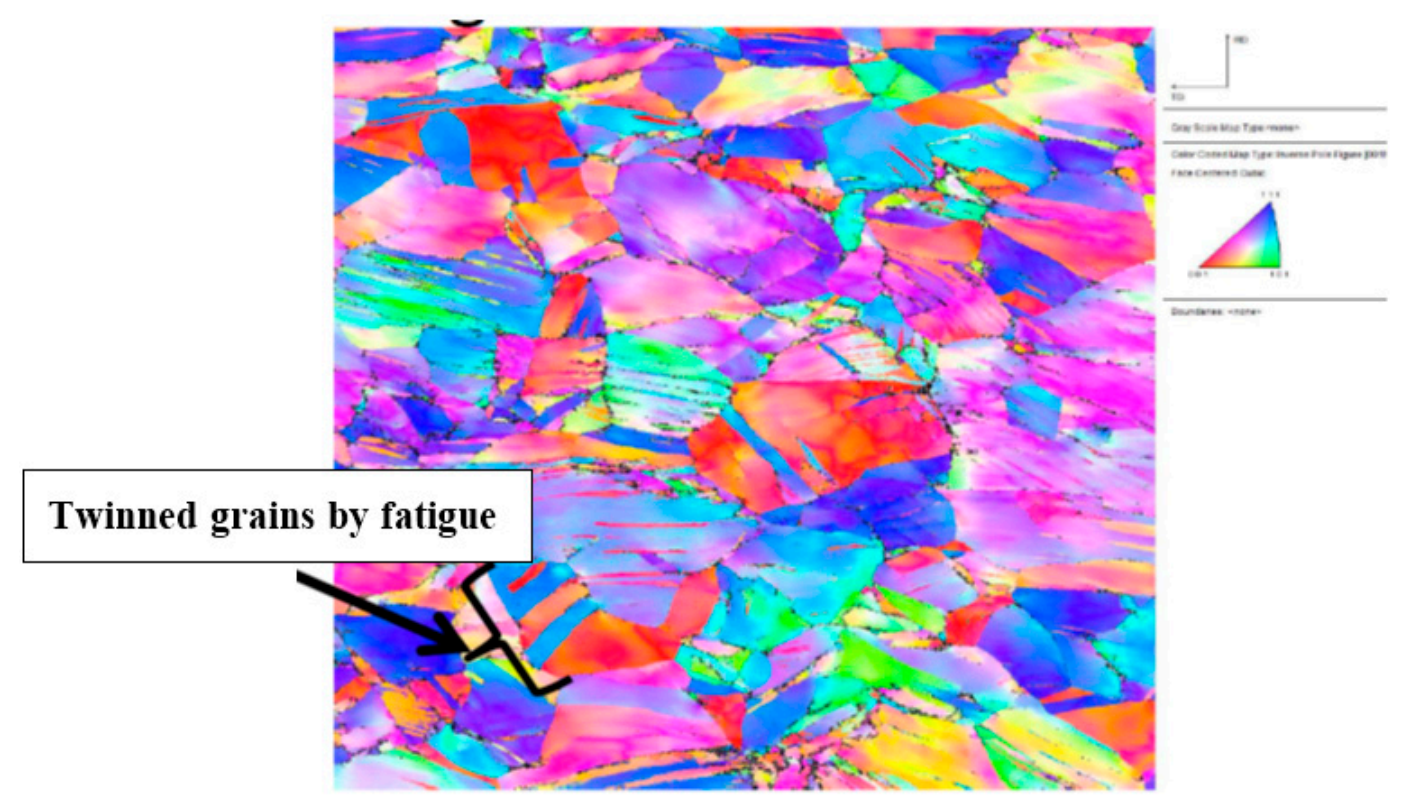

Figure 10. Inverse pole figure showing crystallographic characterization of the plate microstructure showing twinning that may have occurred due to in vivo use by fatigue or a material feature.

The quasi-cleavage and facets seen in Figure 9 are highly characteristic of brittle fracture-an end consequence of corrosion-fatigue crack propagation. Imaging of the distal end of the failed piece on the optical microscope (Figure $7 \mathrm{~b}$ ) showed evidence of progressive fatigue fracture that eventually led to brittle fracture, depicted by the abrupt change in surface pattern. It is this brittle fracture that ultimately led to the failure of the PHILOS.

Azevedo et al. investigated multiple devices (femoral compression plate, femoral nail plate, and oral maxillo-facial plate) and discussed the importance of material conforming to ISO (International Organization for Standardization) and/or ASTM standards for these devices. Most devices investigated [19] failed by a corrosion-assisted fracture that can be traced back to improper chemical composition. Other devices investigated revealed fabrication or assembly defects that contributed to their premature failure [23]. Sivakumar et al. and Marcomini et al also showed that lack of chemical conformity in the alloy had led to the implant failure $[19,20]$. The results from the chemical and mechanical property analysis show a potential lack of conformity to ASTM standard. However, it is also possible that the material procurement protocols may have followed other specifications as the device was then marketed by Synthes (Solothurn, Switzerland). The microstructure of the SS316L, Figure 4, shows, given the orientation of various grains via colors in the Figure, that the grains are randomly distributed indicating a weak texture. The pitting resistance of the material has not been investigated; however, is triggered by the presence of MnS inclusions, not documented for this material.

\section{Conclusions}

Images taken at six weeks post-op showed no evidence of device failure. The implant failed mechanically as well as clinically. Failure in the device construct caused lack of union. The first follow-up X-ray images showing evidence of device failure via screw fracture were taken at 18 months post-op. The average time for tibiotalocalcaneal arthrodesis fusion is about 19 weeks. Since imaging evidence supports device failure initiating between six weeks and 18 months, it cannot be said with certainty that the device maintained its integrity for the amount of time necessary for fusion. The revision surgery implemented a pediatric distal femoral osteotomy plate. There is no follow-up data on the revision. The following are a few reasons that may be considered for the overall failure of the PHILOS plate: 
i As we know that the plate was designed for the proximal humerus, it did not match all the requirements of pantalar arthrodesis. A slight mismatch would give rise to forces sufficient to cause overloading failure.

ii The curvature in the plate is one of the important factors to be considered, due to which unequal load distribution could have taken place.

iii Improper reduction may be due to the device. This improper reduction may have generated excessive loading on the LCP leading to a premature mechanical failure.

iv The qualitative data of composition, non-metallic inclusions, hardness, and tensile strength of the plate show that the material conformity per ASTM standard may be an additional issue controlling the integrity of the device.

$\mathrm{v} \quad$ SEM imaging supports a mechanism of corrosion-fatigue fracture from crack initiation sites in the distal areas of the plate due to the presence of inclusion bodies and pits. These crack initiation sites can then lead to crack propagation towards the proximal area (shown by the striations) and ultimately brittle fracture (supported by the cleavage sites and facets).

Acknowledgments: Gerard Simon, Air Force Research Laboratory, Dayton, Ohio provided access to the characterization facilities. Dinesh Gundapaneni assisted with sample preparation, microstructure and hardness testing of the material.

Author Contributions: Madhurima Vallentyne did the initial work as a part of her independent research, Jason Ina continued the further characterization work. Michael Boin reviewed the patient charts and provided clinical insights. Kathleen Shugart performed the SEM analysis and texture related research. Farah Hamandi performed mechanical tests, theoretical aspects of the paper and in the revisions. Richard Laughlin performed the revision surgery and removed the device components. Tarun Goswami, led this research study, recruited students, medical students and residents, verified the analytical methods and edited or written the body of the paper.

Conflicts of Interest: The authors declare no conflict of interest.

\section{Appendix A}

Table A1. Summary of orthopaedic device failure modes.

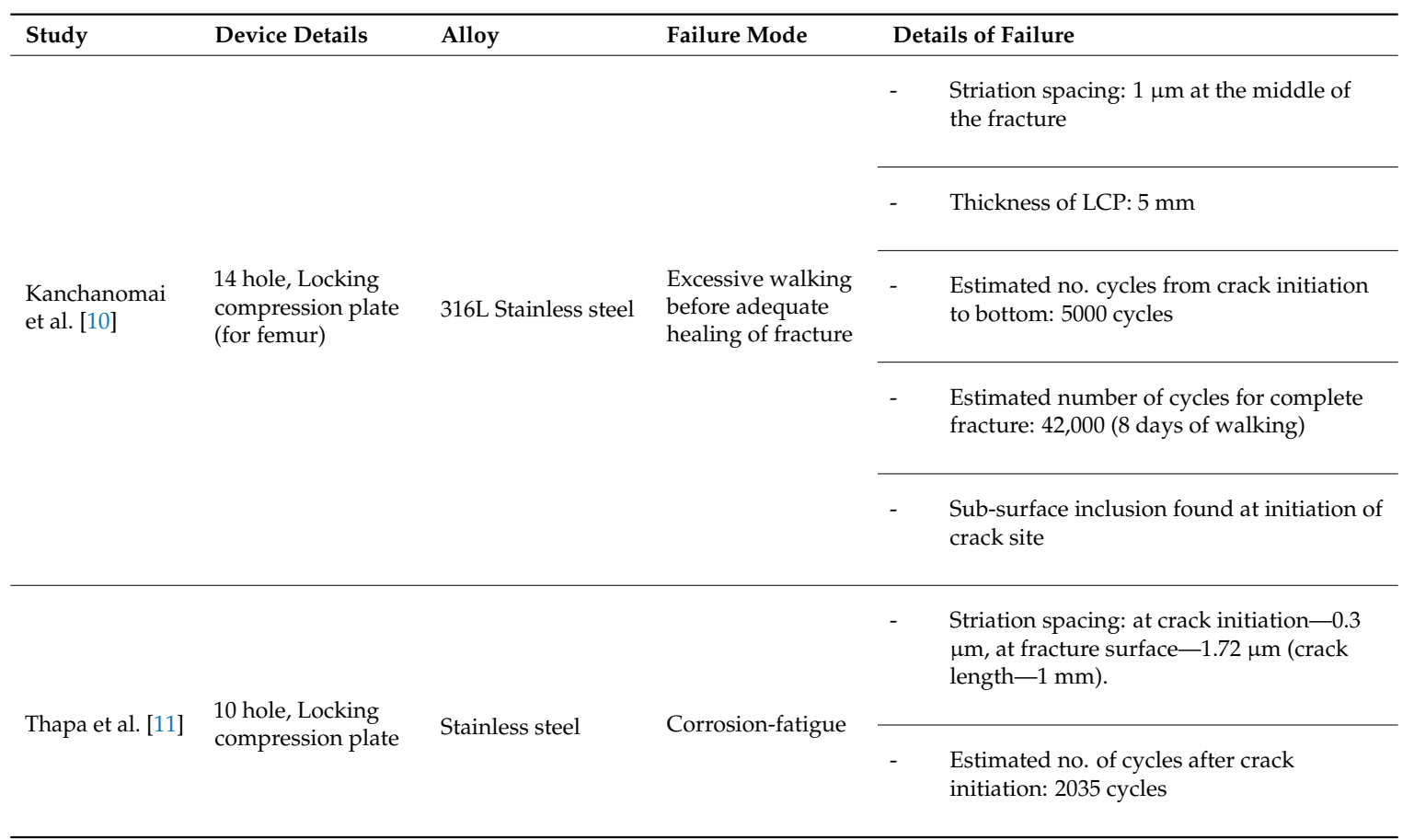


Table A1. Cont.

\begin{tabular}{|c|c|c|c|c|}
\hline Study & Device Details & Alloy & Failure Mode & Details of Failure \\
\hline & & & & - $\quad$ Corrosion (rusting) visible on surface \\
\hline & & & & - $\quad$ Carbon intermetallic-inclusion found \\
\hline \multirow{3}{*}{ Majid et al. [13] } & \multirow{3}{*}{$\begin{array}{l}\text { Lumbar plates } \\
(113 \text { plates } \\
\text { were studied })\end{array}$} & \multirow{3}{*}{ 316L Stainless steel } & \multirow{3}{*}{ Corrosion } & $\begin{array}{l}\text { - } 72.5 \% \text { (majority) of plates } \\
\text { showed corrosion. }\end{array}$ \\
\hline & & & & $\begin{array}{l}\mathrm{Fe}, \mathrm{Cr} \text { and } \mathrm{Ni} \text { (preferential) metal ions were } \\
\text { released into body due to corrosion }\end{array}$ \\
\hline & & & & $\begin{array}{l}\text { - Corrosion occurred at screw-plate interface } \\
\text { (fretting/crevice) }\end{array}$ \\
\hline \multirow[b]{2}{*}{$\begin{array}{l}\text { Varadharajan } \\
\text { et al. [14] }\end{array}$} & \multirow[b]{2}{*}{ Hemi-toe implant } & \multirow[b]{2}{*}{$\begin{array}{l}\text { Cobalt } \\
\text { chromium alloy }\end{array}$} & \multirow[b]{2}{*}{ Failed clinically } & $\begin{array}{l}\text { - } \quad \begin{array}{l}\text { Mechanically intact \& no significant } \\
\text { damage visible }\end{array}\end{array}$ \\
\hline & & & & $\begin{array}{l}\text { Anterior/middle surface exhibited more } \\
\text { scratching/debris deposition-can be } \\
\text { indicative of damage to HMWPE bearing }\end{array}$ \\
\hline \multirow{5}{*}{$\begin{array}{l}\text { Sivakumar } \\
\text { et al. [16] }\end{array}$} & \multirow{5}{*}{$\begin{array}{l}6 \text { hole, Tubular } \\
\text { compression bone } \\
\text { plate (for femur) }\end{array}$} & \multirow{5}{*}{ 316L Stainless steel } & \multirow{5}{*}{ Improper fixation } & $\begin{array}{l}\text { Pitting potential of implant is due to higher } \\
\text { Chromium }-2.3 \% \text { and } \\
\text { Nickel }-4 \% \text { contents. }\end{array}$ \\
\hline & & & & $\begin{array}{l}\text { - Fracture was at } 5 \text { th countersunk hole } \\
\text { of plate }\end{array}$ \\
\hline & & & & $\begin{array}{l}\text { - } \quad \text { "Beach marks" at outer edge of crack } \\
\text { indicate torsional force }\end{array}$ \\
\hline & & & & $\begin{array}{l}\text { - Grain size and inclusion content did not } \\
\text { meet ASTM requirement }\end{array}$ \\
\hline & & & & $\begin{array}{l}\text { Bone plate was placed anteriorly rather } \\
\text { than laterally which does not allow for } \\
\text { proper compression }\end{array}$ \\
\hline
\end{tabular}


Table A1. Cont.

\begin{tabular}{|c|c|c|c|c|}
\hline Study & Device Details & Alloy & Failure Mode & Details of Failure \\
\hline \multirow{3}{*}{$\begin{array}{l}\text { Marcomini } \\
\text { et al. [17] }\end{array}$} & \multirow{3}{*}{$\begin{array}{l}\text { Femoral Locking } \\
\text { compression plate }\end{array}$} & \multirow{3}{*}{$\begin{array}{l}\text { Stainless steel } \\
\text { (not 316L due to } \\
\text { higher content of } \\
\text { Ni and P) }\end{array}$} & \multirow{3}{*}{$\begin{array}{l}\text { Non-conformity of } \\
\text { the material }\end{array}$} & $\begin{array}{l}\text { - } \quad \text { Phosphorus content } 0.26 \% \text { over } \\
\text { superior limit }\end{array}$ \\
\hline & & & & $\begin{array}{l}\text { - } \quad \text { SEM showed evidence of brittle fracture } \\
\text { due to segregation of } P \text { in grain boundaries }\end{array}$ \\
\hline & & & & $\begin{array}{l}\text { Steel was cold worked which contributed } \\
\text { to brittle fracture }\end{array}$ \\
\hline $\begin{array}{l}\text { Cahoon } \\
\text { et al. [18] }\end{array}$ & $\begin{array}{l}\text { McLaughlin plate } \\
\text { for hip ( } 7 \text { other } \\
\text { implants discussed) }\end{array}$ & Cast Vitallium & $\begin{array}{l}\text { Fracture in the area } \\
\text { where maximum } \\
\text { stresses were } \\
\text { expected }\end{array}$ & - $\quad$ Period of time the implant served: 1 year \\
\hline \multirow[b]{2}{*}{$\begin{array}{l}\text { Cahoon } \\
\text { et al. [18] }\end{array}$} & \multirow[b]{2}{*}{$\begin{array}{l}\text { V-Moore plate } \\
\text { and screws }\end{array}$} & \multirow[b]{2}{*}{ 316L Stainless steel } & \multirow[b]{2}{*}{ Crevice corrosion } & - $\quad$ Period of time the implant served: 1 year \\
\hline & & & & $\begin{array}{l}\text { Tissue reaction due to severe } \\
\text { crevice corrosion }\end{array}$ \\
\hline $\begin{array}{l}\text { Cahoon } \\
\text { et al. [18] }\end{array}$ & Nail plate & 316L Stainless steel & $\begin{array}{l}\text { Fracture due to } \\
\text { bending (while } \\
\text { trying to fit the } \\
\text { patient) }\end{array}$ & $\begin{array}{l}\text { Punching of screw holes too close and too } \\
\text { near to the edge of the nail plate }\end{array}$ \\
\hline \multirow{3}{*}{$\begin{array}{l}\text { Azevedo } \\
\text { et al. [19] }\end{array}$} & \multirow{3}{*}{$\begin{array}{l}13 \text { hole } \\
\text { reconstruction } \\
\text { plate for } \\
\text { osteosynthesis }\end{array}$} & \multirow{3}{*}{$\begin{array}{l}\text { Plate: CP Titanium } \\
\text { Screws: Titanium- } \\
6 \mathrm{Al}-4 \mathrm{~V} \text { alloy }\end{array}$} & \multirow{3}{*}{ Corrosion-fatigue } & $\begin{array}{l}\text { - } \quad \text { Reduction of area featured: } \\
55 \% \text { approximately. }\end{array}$ \\
\hline & & & & $\begin{array}{l}\text { Equiaxed } \alpha \text { grains and Intergranular } \beta \\
\text { platelets revealed }\end{array}$ \\
\hline & & & & $\begin{array}{l}\text { - } \quad \text { Corrosion observed on intergranular } \\
\beta \text {-phase which was in contact with } \\
\text { body fluid }\end{array}$ \\
\hline \multirow{3}{*}{$\begin{array}{l}\text { De Medeiros } \\
\text { et al. [20] }\end{array}$} & \multirow{3}{*}{$\begin{array}{l}\text { Hemimandibles } \\
\text { with assistive } \\
4 \text { hole plates }\end{array}$} & \multirow{3}{*}{ 5052-F Aluminum } & \multirow{3}{*}{$\begin{array}{l}\text { Fracture due to } \\
\text { ductile overload }\end{array}$} & $\begin{array}{l}\text { Number of plates fractured in the upper } \\
\text { part of the hole to the right of the fracture } \\
\text { line: } 5\end{array}$ \\
\hline & & & & $\begin{array}{l}\text { - Surface: Dim and grayish showing intense } \\
\text { plastic deformation }\end{array}$ \\
\hline & & & & $\begin{array}{l}\text { Plates failed due to ductile fracture } \\
\text { mechanism alluding to } \\
\text { proper manufacturing }\end{array}$ \\
\hline
\end{tabular}


Table A1. Cont.

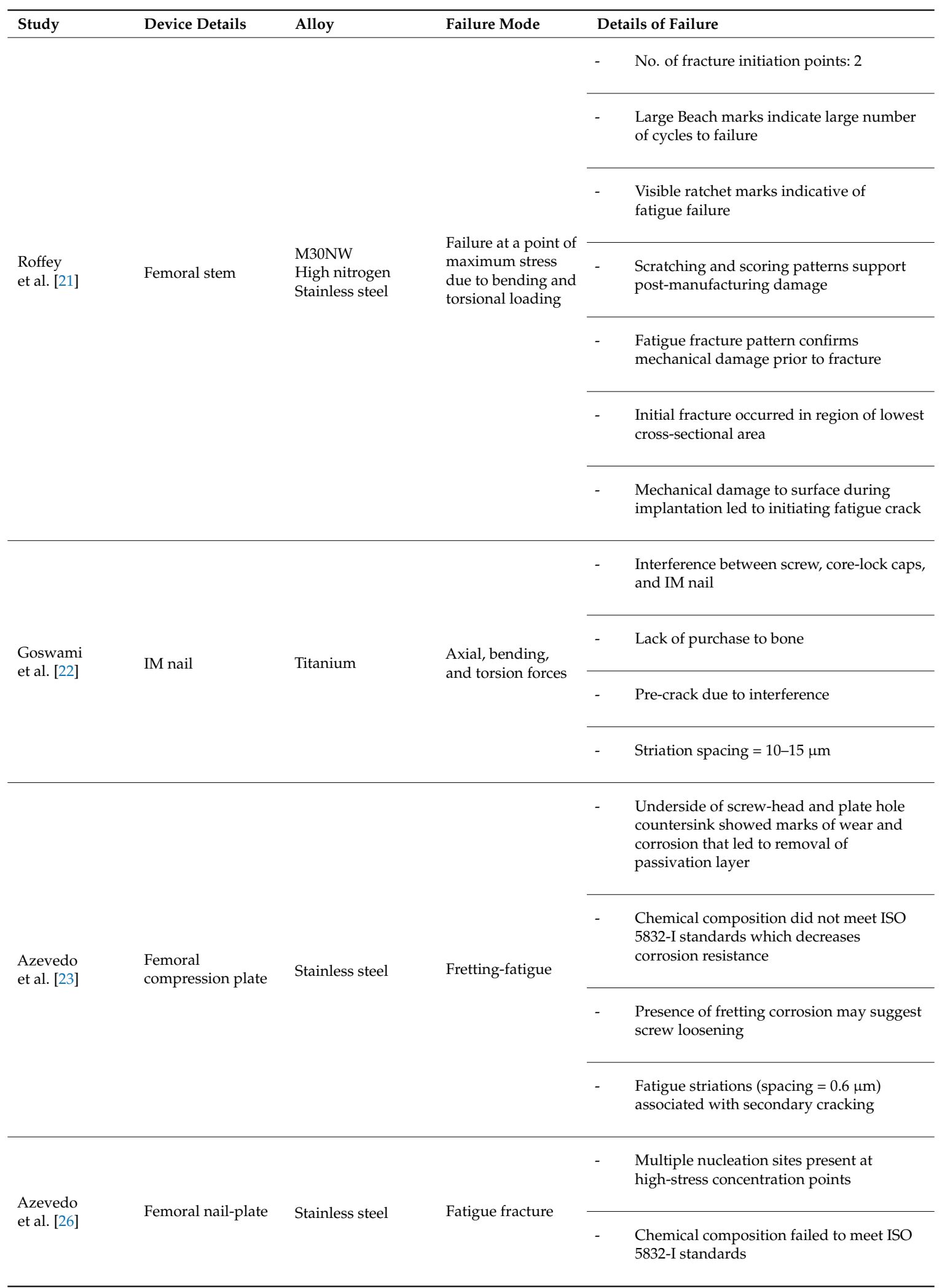


Table A1. Cont.

\begin{tabular}{|c|c|c|c|c|}
\hline Study & Device Details & Alloy & Failure Mode & Details of Failure \\
\hline \multirow{4}{*}{$\begin{array}{l}\text { Azevedo } \\
\text { et al. [23] }\end{array}$} & \multirow{4}{*}{$\begin{array}{l}\text { Titanium oral } \\
\text { maxilla-facial plate }\end{array}$} & \multirow{4}{*}{ CP Titanium } & \multirow{4}{*}{ Corrosion-fatigue } & $\begin{array}{l}\text { Evidence of brittle fracture shown by no } \\
\text { gross plastic deformation near } \\
\text { fracture surface }\end{array}$ \\
\hline & & & & $\begin{array}{l}\text { Presence of fissure striations, complex } \\
\text { furrow structures, secondary } \\
\text { intergranular cracking }\end{array}$ \\
\hline & & & & $\begin{array}{l}\text { Intergranular cracking near surface of } \\
\text { origin indicative of } \\
\text { corrosion-fatigue mechanism }\end{array}$ \\
\hline & & & & $\begin{array}{l}\text { ISO 5832-2 standards were met for } \\
\text { chemical composition of CP titanium }\end{array}$ \\
\hline
\end{tabular}

\section{Appendix B}

\section{Radiological Features Showing Placement of Devices and Gradual Failures}

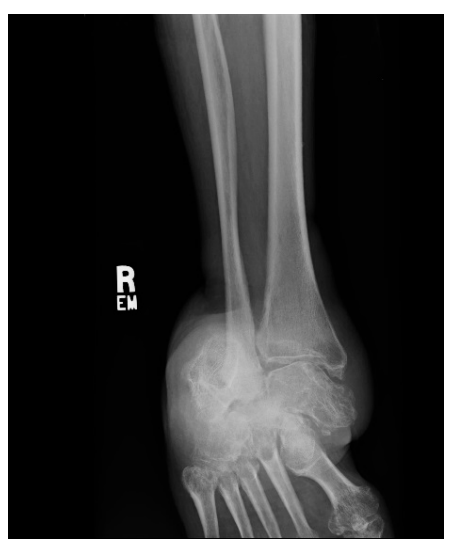

(a)

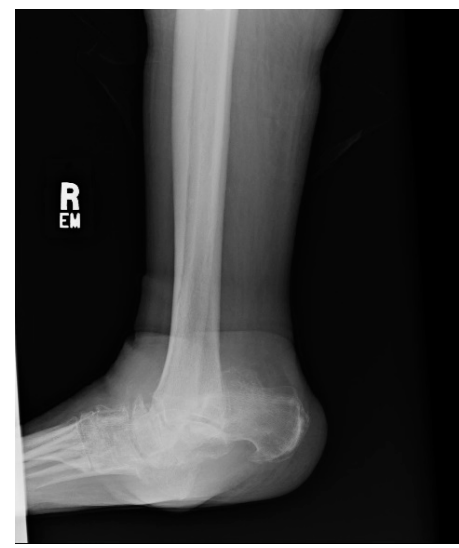

(b)

Figure A1. Initial X-Ray images showing lateral subtalar dislocation with varus tibiotalar joint alignment.

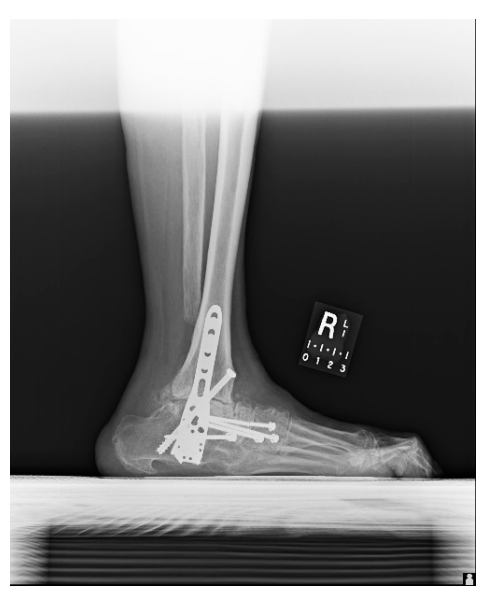

Figure A2. 18 months post-op imaging with evidence of breakage of a distal $3.5 \mathrm{~mm}$ talonavicular screw. 


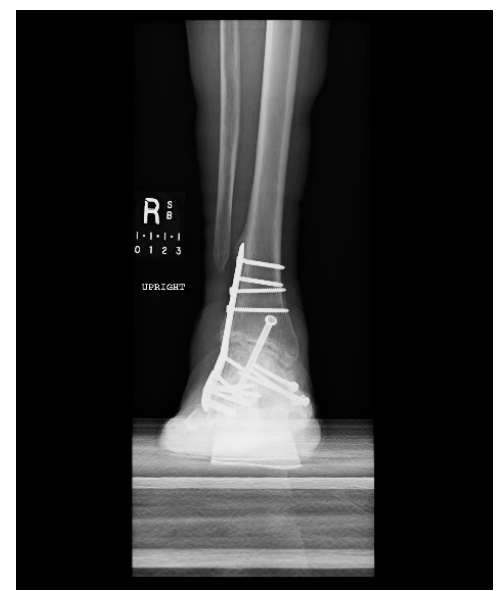

Figure A3. 2 years post-op imaging with screw fracture more displaced and an additional fracture in the proximal $3.5 \mathrm{~mm}$ cortical screw in the tibia.

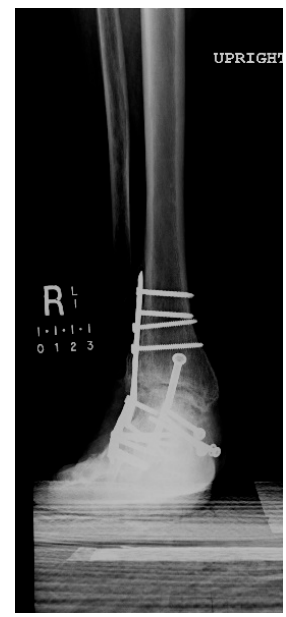

Figure A4. 3 years post-op showing new fracture of the most proximal $3.5 \mathrm{~mm}$ locking screw in the talus.

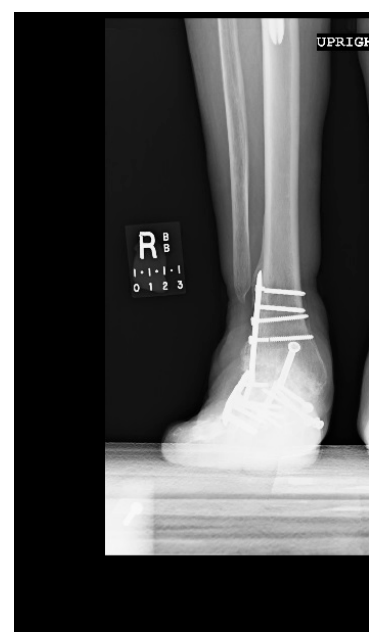

Figure A5. 5 years post-op with additional fractures in a $3.5 \mathrm{~mm}$ cortical screw in the tibia, a second $3.5 \mathrm{~mm}$ talonavicular screw, the $6.5 \mathrm{~mm}$ cannulated screw, and the $3.5 \mathrm{~mm}$ LCP plate. 


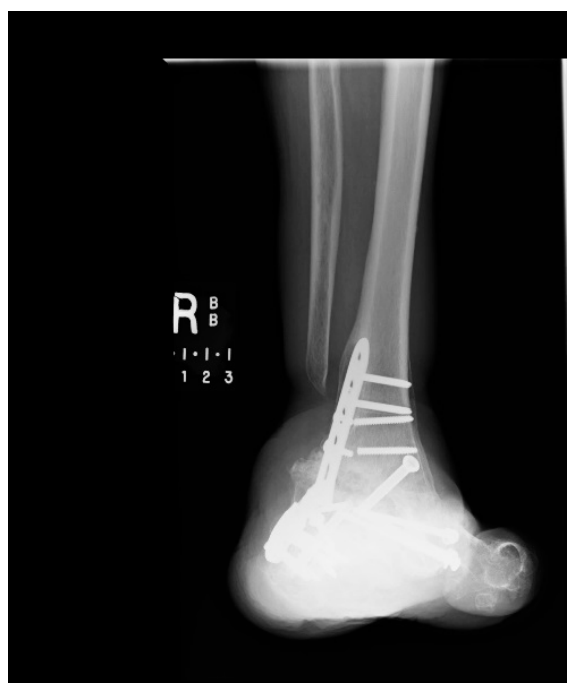

Figure A6. 6 years post-op with an additional fracture in a 3.5 cortical screw in the tibia and the fractured plate became more widely displaced. The valgus deformity seen earlier had now progressed to nearly 30 degrees.

\section{References}

1. Quill, G.E., Jr. Tibiotalocalcaneal arthrodesis. Tech. Orthop. 1996, 11, 269-273. [CrossRef]

2. Coughlin, M.J.; Nery, C.; Baumfeld, D.; Jastifer, J. Tibiotalocalcaneal Arthrodesis with lateral compression Plate. Rev. Bras. Ortop. 2012, 47, 467-473. [CrossRef] [PubMed]

3. Ortho Info. Internal Fixation for Fractures. American Academy of Orthopaedic Surgeons. Available online: https:/ / orthoinfo.aaos.org/en/treatment/internal-fixation-for-fractures/ (accessed on 13 August 2015).

4. Sommer, C.; Gautier, E.; Müller, M.; Helfet, D.L.; Wagner, M. First clinical results of the Locking Compression Plate (LCP). Injury 2003, 34, 43-54. [CrossRef]

5. Kubiak, E.N.; Fulkerson, E.; Strauss, E.; Egol, K.A. The evolution of locked plates. J. Bone Jt. Surg. 2006, 88 (Suppl. 4), 189-200.

6. Ahmad, M.; Nanda, R.; Bajwa, A.S.; Candal-Couto, J.; Green, S.; Hui, A.C. Biomechanical testing of the locking compression plate: When does the distance between bone and implant significantly reduce construct stability? Injury 2007, 38, 358-364. [CrossRef] [PubMed]

7. Desai, K. A Biomechanical Comparison of Locking Compression Plate Constructs with Plugs/Screws in Osteoporotic Bone Model. Master's Thesis, Wright State University, Fairborn, OH, USA, 2010.

8. Ahmad, J.; Pour, A.E.; Raikin, S.M. The modified use of a proximal humeral locking plate for tibiotalocalcaneal arthrodesis. Foot Ankle Int. 2007, 28, 977-983. [CrossRef] [PubMed]

9. Twaij, H.; Damany, D. PHILOS humerus plate for a distal tibial fracture. J. Surg. Case Rep. 2013, 2013 , rjs036. [CrossRef] [PubMed]

10. Kanchanomai, C.; Phiphobmongkol, V.; Muanjan, P. Fatigue failure of an orthopedic implant-A locking compression plate. Eng. Fail. Anal. 2008, 15, 521-530. [CrossRef]

11. Thapa, N.; Prayson, M.; Goswami, T. A failure study of a locking compression plate implant. Case Stud. Eng. Fail. Anal. 2015, 3, 68-72. [CrossRef]

12. Karmacharya, S.; Goswami, T. Analysis of a clinically failed, mechanically intact, reconstructive compression plate. Case Studies in Engineering Failure Analysis. Trauma Cases Rev. 2015. [CrossRef]

13. Majid, K.; Baker, K.C.; Baker, E.A.; Koueiter, D.M.; Herkowitz, H.N. High Rate of Corrosion of 316L Stainless Steel Plates Used in Posterior Thoracolumbar Fixation: A Retrieval Study. In Proceedings of the 55th Annual Meeting of the Orthopaedic Research Society, Las Vegas, NV, USA, 22-25 February 2011.

14. Varadharajan, S.; Laughlin, R.; Goswami, T. Analysis of clinically failed, mechanically intact, hemi-toe implant. Case Studies in Engineering Failure Analysis. J. Biomed. Eng. Biosci. 2016, 3, $22-25$.

15. Sudhakar, K.V. Metallurgical investigation of a failure in 316L stainless steel orthopaedic implant. Eng. Fail. Anal. 2005, 12, 249-256. [CrossRef] 
16. Sivakumar, M.; Kamachi Mudali, U.; Rajeswari, S. Investigation of failures in stainless steel orthopaedic implant devices: Fatigue failure due to improper fixation of a compression bone plate. J. Mater. Sci. Lett. 1994, 13, 142-145. [CrossRef]

17. Marcomini, J.B.; Baptista, C.A.R.P.; Pascon, J.P.; Teixeira, R.L.; Reis, F.P. Investigation of a fatigue failure in a stainless steel femoral plate. J. Mech. Behav. Biomed. Mater. 2014, 38, 52-58. [CrossRef] [PubMed]

18. Cahoon, J.R.; Paxton, H.W. Metallurgical analyses of failed orthopedic implants. J. Biomed. Mater. Res. 1968, 2, 1-22. [CrossRef] [PubMed]

19. Azevedo, C.R.F. Failure analysis of a commercially pure titanium plate for osteosynthesis. Eng. Fail. Anal. 2003, 10, 153-164. [CrossRef]

20. De Medeiros, R.C.; de Moura, A.L.; Rodrigues, D.C.; Mendes, M.B.M.; Sawazaki, R.; Moreira, R.W.F. Fractographic analysis of 2.0-mm plates with a screw locking system in simulated fractures of the mandibular body. J. Oral Maxillofac. Surg. 2014, 72, 1130-1137. [CrossRef] [PubMed]

21. Roffey, P. Case study: Failure of a high nitrogen stainless steel femoral stem. Eng. Fail. Anal. 2012, 20, 173-182. [CrossRef]

22. Gundapaneni, D.; Slocum, M.; Paul, P.; Christof, S.; Goswami, T. Failure Investigation of a Tibiotalocalcaneal Arthrodesis System. Eng. Fail. Anal. 2016, 59, 588-604.

23. SYNTHES. $3.5 \mathrm{~mm}$ LCP Proximal Humerus Plate-Stainless Steel and Titanium Technique Guide. 2002. Available online: http://synthes.vo.llnwd.net/o16/LLNWMB8/US\%20Mobile/Synthes\%20North\% 20America/Product\%20Support\%20Materials/Technique\%20Guides/DSUSTRM10161133_ProxHumP1_ STG_150dpi.pdf (accessed on 9 June 2015).

24. SYNTHES. Small Fragment Locking Compression Plate (LCP) System. Stainless Steel and Titanium-Technique Guide. 2002. Available online: http://synthes.vo.llnwd.net/o16/Mobile/ Synthes\%20North\%20America/Product\%20Support\%20Materials/Technique\%20Guides/SUSA/ SUTGSmFrgLCPJ3908I.pdf (accessed on 9 June 2015).

25. Annual Book of ASTM Standards (Vol. 13.01), American Society for Testing and Materials: West Conshohocken, PA, USA, 2005.

26. Azevedo, C.; Hippert, E. Failure analysis of surgical implants in Brazil. Eng. Fail. Anal. 2002, 9, $621-633$. [CrossRef]

27. Powell, G.W.; Mahmoud, S.E. ASM Handbook, 9th ed.; American Society for Metals: Metals Park, OH, USA, 1986; Volume 11. 